\title{
THE SOVIETISATION OF RURAL AREAS OF LITHUANIA: A CASE STUDY OF THE LENIN'S WAY KOLKHOZ IN DELTUVA (1948-1957)
}

\author{
Antanas Terleckas \\ (Vilnius University)
}

\begin{abstract}
This article presents the story of the establishment of one kolkhoz, Lenin's Way, located in the Deltuva district, as a typical attempt at the Sovietisation of rural Lithuania. The microhistorical approach is applied in the article, facilitating a more specific and detailed illustration of the processes that have been under way in postwar Lithuanian rural areas in historiography up till now. The author does not convey the Sovietisation of rural Lithuania through the prism of the partisan war or terror, but tries to understand the different expectations and ambitions of reform implementers and the ordinary people who suddenly found themselves as part of a kolkhoz. The study suggests looking at collectivisation not as consistent and finite postwar reform, but as a complex process that lasted considerably longer, quite unlike what was claimed by the Soviet regime, which declared that collectivisation had been achieved in Lithuania by 1951.
\end{abstract}

KEYWORDS: collectivisation, kolkhoz, sovietisation, everyday life, Stalinism.

\section{Introduction}

Collectivisation was one of the most brutal and most important reforms undertaken by the Soviet regime that Lithuanian society had to experience in the years following the Second World War. It created a new Lithuanian rural society affected by Sovietisation, which is very difficult to talk about academically, even today. Largely superficial assessments of collectivisation still predominate in the relatively meagre scientific literature available on this topic: it is stated that collectivisation led to the prevalence of alcoholism, the work culture declined, as did agricultural productivity, etc. However, it is still difficult to talk about specific examples that would allow the detailing of these rather abstract statements, as there is a dire shortage of research specifically on collectivisation. Even though 
there are quite a lot of Soviet historical texts written on this topic, of which few qualify as historiographical, ${ }^{1}$ research published after 1990 has clearly been dominated by the themes of resistance, collaboration and terror. For this reason, it has become difficult to imagine rural society under the effects of Sovietisation, as we are accustomed to seeing it through the prism of the partisan war and soviet terror campaigns (deportations). The most important articles about kolkhozes ${ }^{2}$ were written while they were still in existence: these are articles by Liudas Truska written during the years of perestroika which were later revised, ${ }^{3}$ and the article written by Kęstutis Girnius for the journal Soviet Studies, ${ }^{4}$ which has been undeservingly overlooked in historiography. Even though Truska demasks the main lies in Soviet historiography, these articles are not comprehensive studies in themselves; also, over three decades have passed since they were written, and a rethinking of Truska's theses has not yet happened. Probably all later attempts to talk about collectivisation and kolkhozes in Lithuanian historiography in one way or another are mostly paraphrased versions of Truska's theses, which are developed along rather specific lines, where collectivisation becomes a part of the historical context rather than an independent object of research. ${ }^{5}$ One exception would be the article by the sociologist Diana Mincyte that appeared in an issue of Slavic Review in 2009 about the subsidiary plots of

${ }^{1}$ I shall mention only a few of the most important Soviet-period works: M. Gregorauskas, Tarybų Lietuvos žemès ūkis, 1940-196o (Vilnius, 196o); Tarybų Lietuvos valstietija: istorijos apybraiža, ed. H. Šadžius (Vilnius, 1979).

${ }^{2}$ The terms kolkhoz and kolkhoznik are used consciously in this article, rather than 'collective farm' or 'collective farm workers', in order to highlight how this very foreign concept was forced on people from outside, much like the term Soviet is not translated. During the period under discussion, for most of the rural population, the kolkhoz never became a 'collective farm', i.e., a phenomenon they could treat as their own, as part of their identity.

${ }^{3}$ L. Truska: 'Lietuvos valstiečių kolektyvizavimas', in: Lietuvos istorijos metraštis. 1988 metai (1989), pp. 79-9o; Lietuva 1938-1953 metais (Kaunas, 1995).

${ }^{4}$ K. Girnius, 'The collectivisation of Lithuanian Agriculture, 1944-1950', in: Soviet Studies, Vol. 40, No 3 (July 1988), pp. 46o-478.

${ }^{5}$ See, for example, J. Starkauskas, Čekistine kariuomené Lietuvoje 1944-1953 metais (Vilnius, 1998); M. Pocius, Kita mėnulio pusé: Lietuvos partizanu kova su kolaboravimu 1944-1953 metais (Vilnius, 2009). 
land of kolkhozniki. ${ }^{6}$ Incidentally, the history of collectivisation has received more attention from researchers in recent times: in 2018-2019, the journal Genocidas ir rezistencija [Genocide and Resistance] featured a two-part article by Mindaugas Pocius, ${ }^{7}$ mostly analysing material discovered in Russian archives, which revealed the mechanisms for implementing collectivisation that were handed down 'from above'. Also worth mentioning is the essay by Arūnas Streikus, ${ }^{8}$ where a concise but more conceptual assessment than in previous attempts of the outcomes of the Sovietisation of rural Lithuania is presented. There have also been several more studies that highlight the dimension of the village under the effects of Sovietisation. New studies about the Klaipedda region have also appeared, but on account of the repatriation of Germans and the general abandonment of the land, Sovietisation in this part of the country was a more unusual case. ${ }^{9}$ Thus, it is still difficult to understand and gain a deeper knowledge of the historical reality of rural Lithuania under Sovietisation.

Foreign historiography presents a somewhat broader and more detailed history of collectivisation; however, these works often talk about the experiences of the USSR in the 1920 and 1930s, making their application in Lithuanian historical research quite limited. Collectivisation in Lithuania was a different process to what occurred in the USSR: even though the reform mechanism was almost identical, the reforms were implemented in very different historical, geographical and political conditions and periods. Also, for a long time, historians found it much more important to

${ }^{6}$ D. Mincytè, 'Everyday Environmentalism: The Practice, Politics, and Nature of Subsidiary Farming in Stalin's Lithuania', in: Slavic Review, Vol. 68, No 1 (spring 2009), pp. 31-49.

${ }^{7}$ M. Pocius: 'Lietuvos kolektyvizacija 1947-1952 m.: VKP(b) CK sprendimai ir kontrolë', in: Genocidas ir rezistencija, 2018, 2(44), pp. 7-14; Genocidas ir rezistencija, 2019, 1(45), pp. 72-85.

${ }^{8}$ A. Streikus, 'Sovietinis kaimas ir erdvès užvaldymas', in: Modernizacijos traukinyje, pp. 108-117.

${ }^{9}$ S. Kraniauskienė, S. Pocytė, R. Leiserowitz, I. Šutinienè, Klaipėdos kraštas 19451960 m.: naujos visuomenès kürimasis ir jo atspindžiai šeimų istorijose (Klaipėda, 2019); R. Bukavickas, Sovietizacija Klaipèdos krašte: sociokultūrinès ir socioekonominès transformacijos 1945-1960 metais, doctoral dissertation (Klaipėda, 2020). 
understand the implementation mechanism itself of collectivisation, so that social history accounts are also limited in number. The fundamental study Stalin's Peasants by Sheila Fitzpatrick ${ }^{10}$ is an exception, where most attention is focused on the rural population affected by Sovietisation, rather than the reform implementers; there is also Lynne Viola's study about the so-called 25,ooo-ers (dvadtsatipiatitysiachniki). ${ }^{11}$

Historical research on Central-Eastern and East European postwar collectivisation has also received more attention recently, ${ }^{12}$ which includes analyses of the Baltic countries. ${ }^{13}$ Estonia, whose history has been thoroughly researched by David Feest ${ }^{14}$ and Anu Mai Kõll, ${ }^{15}$ has received the most attention of the three Baltic States. Nonetheless, even though collectivisation in the Baltic countries was implemented synchronously (it was launched soon after the resolution of the CPSU(b) CC dated 21 May 1947 'On the Establishment of Kolkhozes in the Lithuanian, Latvian and Estonian SSRs') the experiences of each country differed for various reasons, so we should not think that the reforms took place identically and had the same outcomes: out of all the Baltic States, the armed resistance against the Soviet regime in Lithuania was the greatest and strongest, and Lithuania was the most agrarian and least industrialised of the three countries. This could mean that collectivisation had the direst consequences in Lithuania.

Thus, there is still a need for research on the history of collectivisation in Lithuania, as the academic literature on the topic

\footnotetext{
${ }^{10}$ S. Fitzpatrick, Stalin's Peasants: Resistance \& Survival in the Russian Village After Collectivization (New York, Oxford, 1994).

${ }^{11}$ L. Viola, The Best Sons of the Fatherland: Workers in the Vanguard of Soviet Collectivization (New York, Oxford, 1987).

${ }^{12}$ G. Kligman, K. Verdery, Peasants under Siege: The Collectivization of Romanian Agriculture (Princeton, 2011); The Collectivization of Agriculture in Communist Eastern Europe: Comparison and Entanglements, eds. C. Iordachi, Arnd Bauerkämper (New York, 2014).

${ }^{13}$ See, for example: J. Zubkova, Pabaltijys ir Kremlius 1940-1953 m. (Vilnius, 2010), pp. 198-227.

${ }^{14}$ D. Feest Zwangskollektivierung im Baltikum: die Sowjetisierung des estnischen Dorfes 1944-1953 (Köln, Wien, 2007).

${ }^{15}$ A.M. Kõll, The Village and the Class War: Anti-Kulak Campaign in Estonia (Budapest, 2013).
} 
has not advanced very far since the times of perestroika. ${ }^{16}$ This paper is an attempt to fill in this historiographical gap: it presents an analysis of rural Lithuania under Sovietisation, focusing not so much on the figures who implemented the process as the people who found themselves in kolkhozes. To achieve this aim, I shall analyse the history of one kolkhoz, Lenin's Way, located in the Deltuva district near Ukmergè, with sources from other institutions used as supplementary and control material. Three main reasons determined the selection of this case study: 1) Access to sources: the entire body of documents relating to this kolkhoz is kept in the Vilnius Regional State Archives (col. 157). The most important source for the research were the general and board meeting protocols, and annual reports that contain data about the economic effectiveness of the kolkhoz; 2) The varied nature of the sources: a Party Organisation (PO) operated at the kolkhoz almost from its very inception, and its documents are kept in the Lithuanian Special Archives (col. 90). Other sources were also discovered that supplement the archival material: one example worth highlighting is Tolimos pabares,${ }^{17}$ the memoirs of Juozas Kondratas, the kolkhoz's chairman (from the end of 1954), published in 1971, plus a manuscript of the memoirs that was read by the censor and editor, ${ }^{18}$ which is different to the published version. A diploma paper by K. Žilennienė about the history of none other than the Lenin's Way kolkhoz, which was defended in 1968, was also uncovered in the Manuscript Department of Vilnius University Library. ${ }^{19}$ The appendices in the paper contain the concise recollections of the first kolkhoz chairman,

${ }^{16}$ A good illustration of this is the eclectic monograph published in 2019: A. Balžentis, P. Sasnauskas, K. Starkevičius, Kolūkmetis okupuotos Lietuvos kaime (Vilnius, 2019).

${ }^{17} \mathrm{~J}$. Kondratas, Tolimos pabarès (Vilnius, 1971).

${ }^{18}$ Idem, Tolimos pabares, edited manuscript, in: Lithuanian Literature and Art Archive (Lietuvos literatūros ir meno archyvas, henceforth LLMA), col. 23, inv. 2, file 1620.

${ }^{19} \mathrm{~K}$. Žilėnienė, 'Ukmergės rajono Deltuvos apylinkès „Lenino keliu“ kolūkio istorija', diploma paper, in: Vilnius University Library Manuscript Department (Vilniaus universiteto bibliotekos Rankraščių skyrius, henceforth VUB RS), F85-L153. 
which present unique material about the circumstances of the kolkhoz's establishment; 3) The history of the kolkhoz itself: the farm was founded in an area that belonged to Lithuania (not to Poland or Germany) throughout the whole interwar period, so it is more likely to present a more typical case of the Sovietisation of rural Lithuania. Also, Lenin's Way was founded relatively early (in the summer of 1948). While it initially consisted of just a few families, it grew rapidly; other kolkhozes in the area started being joined to it from 1950, so its history reflects the process of kolkhoz amalgamation as well. As the mechanism for the establishment of a kolkhoz was basically identical, the microhistory approach, which makes it possible to take a more in-depth look at specific details, should offer a relatively representative image of a typical experience of Sovietisation in rural Lithuania.

The chronological boundaries of this study (1948-1957) were chosen for several reasons. The year 1948 was the beginning of mass collectivisation in Lithuania, ${ }^{20}$ and that was the year the kolkhoz under review was formed. The choice of 1957 needs a more detailed explanation. First of all, historiography traditionally denotes 1951 to 1953 as the end of collectivisation in Lithuania, as this was when almost the whole rural population had been forced into kolkhozes. The regime itself stated that collectivisation had ended. But if we choose the regime's reference point, we miss out the processes that took place in kolkhozes after the creation of the institutional network, as most only existed 'on paper' for a long time after their founding. Second, after the death of Stalin in 1953, fundamental changes started to happen in the Soviet system: the regime no longer resorted to mass terror, kolkhozes were also affected by important reforms, and historiographical evidence exists to show that the economic situation of kolkhozes started to improve. The year 1957 is indicated in Soviet historiography and other literature as the year of resurgence in the agricultural sector, the first year when an improvement was noticeable in kolkhozes: in terms of economic indicators, it should perhaps be considered

\footnotetext{
${ }^{20}$ While the formal signal to start collectivisation was issued in May 1947, by the end of that year only 20 kolkhozes had been established in Lithuania.
} 
the actual end of collectivisation; some Soviet-era historians have also made it a threshold year in their papers. ${ }^{21}$

This article seeks to answer the following questions: How was the Lenin's Way kolkhoz founded? Who were the most important people at the kolkhoz? How did it develop after its founding? How did the daily life and well-being of the peasants change once they were part of the kolkhoz? As historical documents from the Stalinist period are rather specific (they are usually more a reflection of fiction and ideology than the historical reality), historical sources themselves become at least in part one of the objects of research. I attempt to reveal how reliable their content is, and what the ideology-infused content reveals, and what historians nevertheless cannot identify from these sources.

\section{The war and the postwar years in the Deltuva district: the historical context of collectivisation}

Deltuva is a small town near Ukmergè (less than ten kilometres away), and was a rural district centre during the years of the First Republic of Lithuania. According to census data, in 1923 the town had a population of 442, and in 1932 the whole rural district had a population of around 9,500. ${ }^{22}$ The Soviet occupation and the beginning of the Nazi-Soviet war soon meant the area became part of the Bloodlands. ${ }^{23}$ Terror became a part of daily life for the population, provoking both fear and opposition to the occupying regimes, which spread to the Deltuva district as well. It is rather common in historiography to talk about the history of collectivisation through a socio-economic prism, so writings about collectivisation often begin with a discussion of Soviet land reform and an analysis of the occupying regime's economic policy: attempts are made to show the separate stages in Soviet economic policy, the last of which was collectivisation. These mechanisms are revealed quite well and in great detail in historiography, so they will not

${ }^{21}$ T. Taršilova, 1948-1957 m. Lietuvos TSR kolūkių metiniu apyskaitų respublikos suvestinès (Vilnius, 1986).

${ }^{22}$ 'Deltuva', in: Lietuviu enciklopedija, Vol. IV (Boston, 1954), pp. 430-431.

${ }^{23}$ T. Snyder, Bloodlands: Europe between Hitler and Stalin (New York, 2010). 
be repeated here. But I would like to stress that processes that are outside the boundaries of economics are of greater significance in understanding the history of collectivisation: the partisan war, Soviet repressions, the growing fear among the population, and increasing uncertainty. These factors changed people's attitudes towards both the regime and the opposition movement, encouraging them to search for new ways of adapting. Foreign historiography devotes quite a lot of attention to this, usually adopting the Bolshevik lexicon and analysing the 'class struggle' under way in rural areas, or the 'bourgeois question'. Nonetheless, this approach places a greater emphasis on the regime, rather than how it all looked from the point of view of the people.

As the front line moved across Lithuania in 1944, Ukmerge was defended by German troops, so at that point the town (including Deltuva) was damaged, but not as much as major cities of Lithuania (Vilnius, Klaipeda, Šiauliai). ${ }^{24}$ The response to the re-occupation by the Soviets was the Lithuanian partisan war. Organised resistance began in Lithuania in the summer of 1944. The borders of the Didžiosios Kovos [Great Fight] and the Vytis partisan military districts crossed the Deltuva district. According to NKVD data, by the autumn of 1944 there were several hundred partisan fighters in the area, ${ }^{25}$ most of whom were probably local inhabitants from around Ukmergè. The partisans resisted all possible means of Sovietisation (e.g. in certain districts it was forbidden to take land being divided up as part of the reforms, it was universally forbidden to take equipment [residential buildings, land, livestock] that belonged to deported inhabitants; death could have been the punishment for breaking this rule), which unavoidably influenced the local population's relationship with the Soviet regime, as the partisans were trying to counteract the Sovietisation of Lithuania. The situation changed each year as the partisan war progressively weakened. After the declaration of a partial amnesty and the MGB operation led by the agent Juozas

${ }^{24}$ Hitleriné okupacija Lietuvoje (Vilnius, 1961), p. 385 .

${ }^{25}$ Note about bandit gangs in the Ukmerge district, 10 October 1944, in: Lithuanian Special Archives (Lietuvos ypatingasis archyvas, henceforth LYA), col. K-11, inv. 1, file 3902, pp. 17-18. 
Markulis, which had the greatest impact on the Great Fight and the Vytis partisan military districts, by the end of 1947 the organised resistance effort here had waned significantly, although some sorties by partisans against the Deltuva district Soviet population were recorded in 1948 and 1949 (specifically against newcomers who settled on land that had formerly belonged to partisans or deportees, and against organisers of kolkhozes) ${ }^{26}$

This context is a constituent element of the area's collectivisation which needs to be understood: at the turn of the 1920 and the 1930s in the USSR, as in Lithuania, collectivisation was the final reform that was meant to take control over rural areas. ${ }^{27}$ In this sense, collectivisation and rural Sovietisation began earlier in Lithuania than on 21 May 1947, when the CPSU(b) CC passed a resolution on the establishment of kolkhozes in the Baltic countries; neither did it begin on 20 March 1948 when a similar resolution was confirmed by the $\mathrm{CPL}(\mathrm{b}) \mathrm{CC}$. During the first postwar years, Soviet rule in Lithuania only reached as far as the cities and the areas where the NKVD army had been displaced. Actual authority in the rest of Lithuania lay in the hands of the partisans, who struggled against Sovietisation; so in rural areas, and even in towns, any identification with the occupying government was not only unpopular but also dangerous. Life under the conditions of permanent war changed people's mentality, and at the same time it changed their relationship with the regime. The hatred of the Soviet regime that had emerged in Lithuania after the deportations of June 1941 was gradually replaced by other feelings, primarily fear. This not only changed attitudes towards the regime (how possible collaboration, or at least adaptation, was viewed), but also attitudes towards the armed resistance, which was growing weaker year by year: increasing numbers of people would view the partisans as 'disturbing the peace', identifying them as the reason why rural areas could not finally enter the state of being 'at peace' which Soviet propaganda promised. Rural areas that had initially actively supported and fed the partisans were

\footnotetext{
${ }^{26}$ Pocius, Kita ménulio pusè, pp. 253, 313.

${ }^{27}$ S. Fitzpatrick, The Russian Revolution (Oxford, 2017), p. 138.
} 
increasingly turning their back on the fighters. This was one of the regime's most important goals: according to Nerija Putinaite, it was precisely the 'life in peace' argument that proved throughout the whole Soviet period to be the most effective at encouraging Lithuanians to adapt to the regime. ${ }^{28}$ This way of life under conditions of constant war lasting over a decade, where there was space for acts of revenge and retaliation, ensured that the desire for peace in Lithuanian society during the Sovietisation process would constantly increase.

\section{Between paper and the reality: the genesis of a kolkhoz}

It was under these conditions that the Lenin's Way kolkhoz started being founded in the Deltuva district in the summer of 1948. It is widely known that neither in Lithuania nor in the USSR did peasants want to join kolkhozes: the reform aroused feelings of fear, which only grew (and were also confirmed) in the postwar years, especially after hearing stories of the failed harvest and famine of 1946 in the USSR, and the arrival of people searching for food in the Baltic countries from the USSR. It was also because the very methods by which kolkhozes were established were not very different to those experienced in the USSR: peasants would usually be forced to attend a meeting where, amid hand raising and signatures, they would be tricked into forming a kolkhoz, they would not be allowed to leave until they signed up for the kolkhoz (in rarer cases, the process would be voluntary, especially if there were a number of activists in the community). ${ }^{29}$ In the initial stages of collectivisation, the first kolkhozes were very small, and usually coincided with the boundaries of one or more former villages: the plan was that all the farms in an area would become part of a kolkhoz, and over the course of several years, these small farms would be enlarged. Even official Soviet documents indicate that

\footnotetext{
${ }^{28}$ N. Putinaitè, Nenutrūkusi styga: prisitaikymas ir pasipriešinimas sovietu Lietuvoje (Vilnius, 2007), p. 79.

${ }^{29}$ Viola, Best Sons of the Fatherland, p. 91; M. Martinaitis, Mes gyvenome: biografiniai užrašai (Vilnius, 2010), pp. 161-163.
} 
this reform would have been impossible to implement without coercion, while an especially important factor in collectivisation were the mass deportations of 1948 and 1949, and the overall feeling of fear of being deported that prevailed among the local population. As part of Operation Vesna, on 22 and 23 May 1948, a total of 1,617 people (48o families) were deported from the Ukmerge area, ${ }^{30}$ reaching 40,000 people from all over Lithuania.

In the case of the Lenin's Way kolkhoz, it is likely that the minutes from the constitutive meeting did not make it into the logbook, and have not survived. The first surviving document is minutes of a meeting held on 14 August 1948, when 26 kolkhoz members decided on the surnames of another 39 potential kolkhoz members. Among them was the surname of the kolkhoz's chairman, Povilas Šemiota. ${ }^{31}$ The Ukmerge district newspaper Tarybinis kelias [The Soviet Way] announced the establishment of the kolkhoz on 7 August: it claimed that 39 peasants from the villages of Deltuva and Gintarai had expressed their wish to form a kolkhoz in Deltuva. ${ }^{32}$ Nonetheless, it was more often government officials who inspired the creation of kolkhozes, and not the initiative of the local population, which is obvious in this case as well. As Žilènienè stated in 1968, the 50 surviving declarations to be accepted into the kolkhoz were written in identical handwriting: they were all drafted by one person, while the others were simply coerced into signing. ${ }^{33}$ This is confirmed in the recollections of Šemiota, the first chairman of the kolkhoz, which were written down by Žilènienè in 1968: 'The organisers had a hard time until they convinced the peasants. Sometimes a farmer would hold out for two whole days before signing. They managed to round up 62 farmers for the kolkhoz, but they all vanished pretty quickly. Only eight landless peasants and farmers with small plots of land

${ }^{30}$ E. Grunskis, Lietuvos gyventojų trèmimai 1940-1941, 1945-1953 metais (Vilnius, 1996), p. 194.

${ }^{31}$ Lenin's Way kolkhoz general meeting minutes, 14 August 1948, in:Vilnius Regional State Archives (Vilniaus apskrities archyvas, henceforth VAA), col. 157, inv. 1, file 1, p. 1.

${ }^{32}$ 'Deltuviečiai jungiasi ị kolūkius', in: Tarybinis kelias, 7 July 1948.

${ }^{33}$ Žilènienè, 'Ukmergès rajono Deltuvos apylinkès „Lenino keliu“ kolūkio istorija', pp. 18-19. 
remained. The peasants who did not want to join the kolkhoz lost their land, it was handed over to the kolkhoz. ${ }^{34}$ In this way, land was taken away from the local farmers and peasants.

Even though there was no shortage of articles about the life of local farmers in the regional press, until April 1949 there were no other mentions of the Lenin's Way kolkhoz in the printed media. During that time, there were just a few kolkhoz meetings, and the minutes from one indicated, as Šemiota mentioned, that the kolkhoz was made up of just eight farmers, ${ }^{35}$ meaning that it was not functioning at all. From August to November 1948, at least ten farming families wrote official notes to the kolkhoz board declining to participate in the kolkhoz's activities, ${ }^{36}$ although most of them recanted in 1949. Only in the spring of 1949 did the number of kolkhozniki at Lenin's Way increase again, and was more or less stable. From this point on, numbers continued to grow; a direct influence on this was the Priboj deportation operation on $25^{-28}$ March 1949, which again frightened the local population. Note that the very next day after the deportations (29 March), a meeting was held that was clearly out of context: no organisational matters relating to the kolkhoz were discussed at the meeting, and its very function appears to have been quite different, mobilisation, something like the 'Two Minutes Hate' described in Orwell's 1984. The meeting started with and was mostly in the hands of 'guests' rather than kolkhoz members: these guest speakers were district Party members and security or administrative apparatus functionaries (their exact positions are not indicated). They spoke about how the bourgeois element had infiltrated the kolkhoz, and that the situation was rather bad: only 13 families worked at the farm, while the rest were 'neither working, nor not working, just standing in the middle of the road'. ${ }^{37}$ Even though the 'guest' factor was quite

34 'Buvusio „Lenino keliu“ kolūkio pirmininko Šemiotos Povilo prisiminimai', in: Žilènienė, 'Ukmergès rajono Deltuvos apylinkès „Lenino keliu“ kolūkio istorija', p. 109.

${ }^{35}$ Lenin's Way kolkhoz meeting minutes, 24 October 1948, in: VAA, col. 157, inv. 1, file 1, p. 3 .

${ }^{36}$ See: Peasants' applications for membership of the kolkhoz, in: VAA, col. 157, inv. 1, file 2.

${ }^{37}$ Lenin's Way kolkhoz meeting minutes, 29 March 1949, in: VAA, col. 157, inv. 1, file 1, pp. 8-9. 
important in this case, nevertheless, the kolkhozniki who gathered realised the rules of the game that was being played, and became more involved: they promised to work and stay in the kolkhoz, while the three exposed 'bourgeois infiltrators' (none of whom, incidentally, were ever deported, even though at least two of the three had appeared on the lists of kulaks ${ }^{38}$ and the daughter of the third one had been sentenced to five years of imprisonment for being a partisan messenger $)^{39}$ were forced to leave the kolkhoz. Kõll's research shows that this was not an isolated case. Mass terror campaigns must have been a unique factor mobilising people to join kolkhozes: after the mass deportation campaigns, there would be an upsurge in expressions of hate towards the bourgeoisie and class enemies, etc, in minutes. She explains this as a self-protection mechanism used by peasants in the presence of terror. ${ }^{40}$

The importance of terror in the history of collectivisation cannot be underestimated. Perhaps the meeting which followed the second-largest deportation operation in Lithuania was a turning point in the history of the Lenin's Way kolkhoz. Gradually, from a small economic unit comprising just several families, the Lenin's Way kolkhoz turned into a large body that combined with another seven kolkhozes between $195^{\circ}$ and 1954, maintaining the same name.

This dynamic in the number of members adds extra details and context to the statistics so often given in historiography about the pace and scope of collectivisation. By showing the ever-increasing percentages in the implementation of collectivisation, it is suggested that the reform was unidirectional and finite. Nonetheless, it is obvious that in most cases, the establishment of a kolkhoz was merely a formality 'on paper'. Even when one was founded, the farmers still tried to manoeuvre around the situation, and their reactions to the establishment of kolkhozes was much more varied and dynamic than would appear at first sight. Even though

${ }^{38}$ Deltuva County Executive Committee of the Soviet of Workers Resolution No 46, 24 September 1948, in: VAA, col. 48, inv. 1, file 19, p. 65 .

${ }^{39}$ I thank my colleague Enrika Kripienè for checking this information.

${ }^{40}$ Kõll, The Village and the Class War, p. 65 . 
in this specific case strong acts of opposition could not be found, in other locations in Lithuania the opposition was prevalent and took on different forms. One of the more common modes of recourse was destroying kolkhoz documents. Reports from higher institutions show that peasants would write asking to be released from the kolkhozes; when these requests were rejected, they would try to recover their application documents by resorting to drastic measures. For example, in $195^{\circ}$ all the documents from nine kolkhozes in the Giedraičiai rural district were destroyed. In the Vievis rural district, documents from two kolkhozes were discarded in front of the executive committee building. In the Semeliškès district, 29 kolkhozes simply handed over documents to the executive committee. At one kolkhoz, a female accounts keeper who refused to return farmers' applications to join the kolkhoz was physically assaulted by women. ${ }^{41}$ MGB data shows a similar situation in other districts across Lithuania. ${ }^{42}$ This kind of outburst demonstrates that even in 1950, social ties in rural Lithuania had not yet broken, and that opposition to the state did exist in one form or another: the Soviet system was not capable of achieving the total dissolution of social ties, or transforming peasants into an obedient mass.

On the other hand, even when kolkhoz documents were destroyed, actual withdrawal from the kolkhoz was mostly possible only in theory. Enormous taxes would have to be paid to the state, those leaving kolkhozes could be treated as potential anti-Soviet elements; and besides, peasants who did try to withdraw from kolkhozes very rarely got their land back, and the confiscated equipment would not be returned. This situation in 1948-1950 confirms again the fact that regardless of all the Soviet regime's measures, Lithuania's rural population despised the possibility of living as part of a kolkhoz, and the only realistic way to implement the collectivisation of agriculture was coercion (economic, physical and psychological).

${ }^{41}$ Board of Kolkhoz Affairs under the USSR Government representative to the LSSR report for July 1950, in: Lithuanian Central State Archives (Lietuvos centrinis valstybès archyvas, henceforth LCVA), col. 159, inv. 1, file 2, p. 67 .

${ }^{42} \mathrm{~J}$. Starkauskas, Represiniu struktūru ir komunistu partijos bendradarbiavimas itvirtinant okupacini režima Lietuvoje 1944-1953 m. (Vilnius, 2007). 
Otherwise, the only people to join kolkhozes at their own free will would have been sympathisers of the regime or opportunists. Juozas Baltušis, a famous Soviet Lithuanian writer, was convinced of this when he made the following statement in his notebook in 1948 after travelling around the first kolkhozes and other villages: 'If you just mention the kolkhoz, you're sure to get a whack over the head, and you never know where it'll be coming from.' ${ }^{43}$

\section{Kolkhoz power institutions}

One of the first tasks a kolkhoz faced when it had just started operating was allocating positions and establishing a structure. District (from 1950, regional) executive committees would control who would be appointed chairman (the executive committees were supervised in turn by Party committees); however, a board, brigade leaders and farm managers, etc, also had to be appointed. At the beginning of collectivisation, people were rarely interested in taking on responsible positions in kolkhozes: during the partisan war, these people were more likely to be the targets of partisan reprisals; also, the state apparatus itself appeared threatening, while the majority simply did not want to be actively involved in life in the kolkhoz system. On the other hand, in areas where the war had ended or was nearing the end, there were practically no other control mechanisms, except for sustained psychological fear: even though the life of kolkhoz in theory was strictly regulated, because of Soviet bias towards its cadres, by avoiding any gross negligence or scandals, a person could quite easily get by without having to accept any serious responsibilities.

When a kolkhoz was established, the peasants would find themselves in a complex bureaucratic system, where it was difficult to accurately identify the highest rank in the hierarchy, and at the same time, any precise control mechanisms. Some of the bureaucratic mechanisms served as external obligations placed on the kolkhoz; others operated internally, and the nature and power

\footnotetext{
${ }^{43}$ Notebook of Juozas Baltušis, in: Manuscript Department of the Institute of Lithuanian Literature and Folklore (Lietuvių literatūros ir tautosakos instituto Rankraščiu skyrius, henceforth LLTI RS), F6o-1109, p. 15.
} 
leverage of each one was different. Of the external obligations, the kolkhoz's accountability to the district, state duties and plans, and contracts with the Machine and Tractor Stations (MTS) for sowing and harvesting, should be mentioned, as well as the politbranches of the MTS. We should also mention sowing and livestock control, which was carried out by incoming agronomists, productivity and stock-breeding experts, many of whose competences, acquired against the backdrop of Lysenkoism, aroused scepticism among people who had been involved in agriculture all their lives. There is no shortage of ironic comments in fiction and personal documentary material about the work done by such specialists.

The internal structure of a kolkhoz was somewhat more complex. The chairman became one of the most distinctive symbols of collectivisation, even though the system itself did not give this figure so much importance in theory: in the initial Standard Charter for an artel from 1930, the position of chairman did not even exist. ${ }^{44}$ According to the Standard Charter for agricultural artels (and later editions), which defined procedures at each kolkhoz, formally, the most important governing institution in a kolkhoz was the general meeting, ${ }^{45}$ with the management of the kolkhoz between meetings delegated to the board and the kolkhoz chairman. There could have been cases where at the start, general meetings were held relatively often, and did actually solve fundamental questions relating to life at the kolkhoz: as has been mentioned, at first kolkhozes would be formed from the families of one or several villages, who learned how to live in the Bolshevik way' together. ${ }^{46}$ This meant that a general meeting could occur with relative frequency, while village inhabitants who knew each other well would try to adapt to the Soviet reality. The boards of such smaller kolkhozes would consist of just one, two or three members, and an appointed or elected chairman who did not really gauge what was happening under the new conditions. This was often someone who had some authority in the village community

${ }^{44}$ Fitzpatrick, Stalin's Peasants, p. 185.

${ }^{45}$ Standard Charter for agricultural artels (Vilnius, 1949), pp. 24-25.

${ }^{46}$ Cf. 'Speaking bolshevik', see: S. Kotkin, Magnetic Mountain: Stalinism as a Civilization (Berkeley, Los Angeles, 1997). 
and whom the local people trusted. This kind of case has been covered in the memoirs of the writer Marcelijus Martinaitis. ${ }^{47}$ Such people, at least initially, did not even intend to communalise the equipment or organise collective work: it can be considered an attempt by the former Lithuanian country order to adapt to the changed reality, when the community would manage to avoid the former regime's control or the enthusiastic efforts of the kolkhoz chairman for at least some time following its establishment. A number of rather curious ways that kolkhozes operated have also been recorded. For example, Jelena Zubkova discovered a case in Russian archives where, during a meeting, one Lithuanian kolkhoz not only decided to help the partisans, but also recorded in documents how much of their own inventory it would give them (15 tonnes of grain, and 5,00o roubles). According to Zubkova, there were more cases like this, only other kolkhoz boards did not enter all this information in their minutes. ${ }^{48}$ While I have not come across cases like the one Zubkova cites, it is widely known that there were kolkhoz chairmen who actively supported the partisans. The likely conclusion is that it was an expression of the primary stage in learning how to 'live in the Bolshevik way' under the conditions of collectivisation, where the establishment of a Soviet institution did not lead to any fundamental changes.

Nonetheless, the importance of general meetings soon declined: they were no more than a venue for mechanical voting for resolutions made by the board or chairman. This was also related to the beginning of kolkhoz amalgamation: in 1949 there were $6,03^{2}$ kolkhozes in Lithuania, and by 1951 the number had fallen by half to $2,923 \cdot{ }^{49}$ Whereas up till then most issues relating to sowing or agricultural stocktaking would be solved at general meetings, they gradually lost this function, and the power centre of a kolkhoz clearly shifted to the board, whose activities were dictated by the chairman. Board meeting minutes became rather more comprehensive and longer than general meetings, even

\footnotetext{
${ }^{47}$ Martinaitis, Mes gyvenome: biografiniai užrašai, p. 162.

${ }^{48}$ Zubkova, Pabaltijys ir Kremlius, p. 222.

${ }^{49}$ Tarybu Lietuvos valstietija, p. 121.
} 
though the number of kolkhozniki participating in general meetings was ten times greater. Formally, the Soviet regime considered this a problem, but it did not look for a solution: it would simply be stated in kolkhoz inspection reports that 'dangerous elements' had infiltrated the kolkhoz, who had taken the management of the kolkhoz into their own hands, ignoring the peasants and not organising general meetings..$^{\circ}$ Nonetheless, this kind of shift in power was a natural outcome of the collectivisation system. First of all, kolkhozes soon learned how to exist (or at least to imitate this existence) without constant meetings, the organisational structure stabilised somewhat, and relations between regional government institutions and kolkhozes settled down. Second, when amalgamation began, it became physically difficult to organise frequent meetings, and the small 'family' kolkhozes disappeared. Ultimately, groups of people formed who were interested in serving on the boards, out of careerism and opportunism, and for easier access to the kolkhoz's resources, and to have power over others. These board members were not interested in organising frequent meetings, where their laziness or oversights would be highlighted; their purpose was to remain in power. It is precisely a group of this kind of people who feature most prominently in the documents of the Lenin's Way kolkhoz: ten to 15 surnames appear regularly among those who held the most important positions in the life of the kolkhoz. In this way, even in the second half of the 2oth century, an ordinary village inhabitant remained no more than one of the 'silent majority', much as in the Middle Ages.

As Fitzpatrick has stated, the chairman was the mediator between the state and the kolkhoz. $\cdot^{51}$ This was due to the chairman's peculiar position between two poles: he could favour either the kolkhozniks (hand over the worst part of the harvest to the state, secure greater support for the kolkhoz through his blat connections, etc), or take the side of the state. In the case of the USSR, Fitzpatrick relates this to the chairman's origins: it depended on

$5^{5}$ Board of Kolkhoz Affairs under the USSR Government representative to the LSSR report on work for the first quarter of 1950, in: LCVA, col. R-159, inv. 1, file 2, pp. 6-12.

${ }^{51}$ Fitzpatrick, Stalin's Peasants, p. 186. 
whether he was a local, or whether he had been sent in from other regions. If he had no connection with the local community, he was more likely to be biased towards his direct superiors, and show less leniency to the kolkhozniki under him. In the case of Lithuania, this distinction would not appear to be so fundamental, if only due to the smaller area of the country; so other factors must have been at play, most importantly the chairman's career, his attitude, character, connections with the regional leadership, and also the situation of the kolkhozniki themselves, the extent of their adaptation to the new order, and their overall disposition. By Soviet standards, Šemiota, the first chairman at the Lenin's Way kolkhoz, was a person with an unblemished reputation in the eyes of the regime: he had started working on the Deltuva district executive committee in 1945, and had earned a name among the local population as an ardent communist..$^{2}$ He was a Party member from 1930, and had received the Order of the Badge of Honour in 1949 for his revolutionary activities in 1918 and $1919 ;{ }^{53}$ so his candidature for the position of kolkhoz chairman was not accidental.

As was mentioned earlier, the kolkhozes were by no means an autonomous institution: they depended on the district, and especially the regional, leaders. This dependence was both political (these institutions provided new cadres and chairmen, and exerted control of the kolkhozes) and economic: the redistribution of the material goods occured at the regional level of production, which was critical for the kolkhoz's survival (let alone its expansion), so even regional officials gained enormous leverage over influence. According to Fitzpatrick, USSR regional committee officials sometimes placed such importance on their posts that expressions of a personal cult were evident at a local level. ${ }^{54}$ We may doubt the existence of this kind of independence in the regions in Lithuania,

\footnotetext{
${ }^{2}$ Boleslovo Miškinio-Šarūno atsiminimai, in: Aukštaitijos partizanu prisiminimai, Part III, ed. R. Kaunietis (Vilnius, 2001), p. 467.

53 'TSRS Aukščiausios Tarybos Prezidiumo įsakas Dèl Lietuvos TSR darbininkų, valstiečiu ir priešakinės inteligentijos atstovų apdovanojimo ordinais ir medaliais', in: Tarybinis kelias, 23 July 1949.

${ }^{54}$ Fitzpatrick, Stalin's Peasants, p. 183.
} 
due to the specific nature of its history and geography, but it is precisely here that we can see the importance of the kolkhoz chairman: in one way or another, he had to get his hands on goods that were under the region's administration. This access and the scale of redistribution of production would often depend on the chairman's informal connections and his personal qualities, rather than the conditions dictated by the system itself. It was not just his relations with the regional committee that influenced this, but also how well he negotiated with the MTS. For example, a problem was recorded in the MTS Party organisation meeting reports of Molètai, a town 40 kilometres from Ukmergè, that the MTS technical equipment was being used at kolkhozes with which it had not signed contracts, while staff ignored the contracts that did exist. ${ }^{55}$ It made no sense to them to operate according to the rules (contracts) of the Soviet system. That is why the figure of the chairman was so critical, and why holding this position was so appealing: for the material perks and the power gained, the lack of control and accountability, and the system's bias. Probably the only serious threat to a kolkhoz chairman were the partisans.

There is certainly no shortage of passages in Soviet fiction about the tense relations between the chairman and the rest of the board. Even though minutes are not a very informative source regarding the matter, it is sometimes evident (based on who was speaking, how often, how they handled 'criticism and self-criticism', and what they drew attention to) that at least some of the board members did not always agree with the chairman. This became particularly obvious at meetings where a representative from the regional leadership was present: the scale of the criticism and self-criticism, especially addressed to the chairman, increased significantly. On one hand, this was how board members declared their loyalty to the system; but they also possibly hoped to earn a favourable recommendation in the eyes of their 'patrons', hoping to either take over the chairman's position or to be transferred to work somewhere outside the kolkhoz.

${ }^{55}$ Molètai district Kaližai county MTS Party Organisation meeting minutes, 5 July 1952, in: LYA, col. 4767, inv. 1, file 1, p. 9 o. 
Another separate source of power in life at a kolkhoz was the Party organiser (partorg). It is likely that tension between the board and the founders of the Party Organisation was not a rare phenomenon; however, at the start of collectivisation, the process of creating Party organisations did not go very smoothly. According to official data, in Lithuania as of 1 January 1952, Party organisations existed at only 13.3 per cent of kolkhozes (391 out of 2,939), and by 1 January 1959 this number had reached 71.4 per cent. ${ }^{6}$ In the case of the Lenin's Way kolkhoz, a Party Organisation was founded there in January 1949, and it appears that greater tensions were avoided: the first partorg came from local peasant origins, he joined the board at its very inception, and later on the kolkhoz board members were the most prominent in the Party Organisation's activities. At the first Ukmerge district Party conference held in late December 1950, the whole kolkhoz Party Organisation was criticised in public for not taking any measures to stop chariman's Šemiota's drunkenness. ${ }^{57}$ Yet there were other cases as well, for example, in 1953 at a meeting of the Molètai region's First of May kolkhoz Party Organisation, the board was criticised, not just for being negligent in when and how the livestock was being fed, or how much the kolkhozniki were stealing, but that they were not even visiting the farms, and had no idea what the conditions were like there..$^{8}$ Writers may also have noticed these tensions when they visited kolkhozes, and later conveyed these realities in their work. In a play published in 1956 called Anksti ryteli [Early in the Morn'], Baltušis characterises these relations as a dialogue between the kolkhoz chairwoman and the partorg who was listening to her: 'You must understand me. We are standing alongside each other, at the very front of the kolkhoz, and yet we cannot find one another.'59

${ }^{56} \mathrm{~V}$. Bartuška, 'Lietuvos KP kaimo pirminių organizacijų veikla, vystant žemdirbių gamybinị aktyvumą 1952-1958 metais', in: Už socializmo sukūrimą Lietuvoje (Vilnius, 1969), p. 395.

${ }^{57}$ Ukmerge District First Party Conference (28-29 December 1950) minutes, in: LYA, col. 4510, inv. 1, file 2, p. 81.

${ }^{58}$ First of May kolkhoz Party Organisation meeting minutes, 27 September 1953, in: LYA, col. 83, inv. 1, file 2, p. 18.

${ }^{59}$ Notebook of Juozas Baltušis, in: LLTI RS, F6o-1109, p. 15. 


\section{Problems identifying the economic development of kolkhozes}

Lithuanian agriculture shrank steadily from 1940. At first it was hit by the Soviet land reform, and later by enormous grain taxes (paid in kind) and other taxes during the Nazi occupation, which led to a reduction by half of separate agricultural sectors (such as livestock breeding).$^{60}$ A slight economic recovery was noticeable in the years 1944 to $1946,{ }^{61}$ but it should not be overemphasised: these years were the peak of the partisan war, and it was not long before peasants' farms were weighed down by even higher taxes, a burden that could only be shed by joining a kolkhoz.

It is no secret that in the first years, the situation of peasants who ended up in the kolkhozes was pitiful, the economic output of the whole country dropped significantly, and even in Soviet literature the first year of relative recovery is denoted as $1957 .{ }^{62} \mathrm{It}$ is difficult to assess the decline accurately, as many sources from this period are not considered reliable, ${ }^{63}$ although one thing is clear: the main aspect helping a kolkhoznik to survive was the semi-private o.6-hectare subsidiary plot of land, for until 1957 the communal economy only constituted 15 to 20 per cent of his earnings. ${ }^{64}$

Annual reports should reveal the most about the economic viability of a specific kolkhoz, for they contain detailed records of the harvest, the number of livestock, the natural increase in livestock, the output of the kolkhozniki, and so on. Data from these reports is the main source that the economic statistics for the first decade under collectivisation were based on, as reports would be sent to regional executive committees and agricultural departments, and from there to the Ministry of Agriculture,

${ }^{60}$ A. Bubnys, Vokiečiu okupuota Lietuva (1941-1944) (Vilnius, 1998), p. 333.

${ }^{61}$ Girnius, 'The collectivisation of Lithuanian agriculture', pp. 46o-461.

${ }_{22}$ 'Kolūkiai, kolektyviniai ūkiai', in: Mažoji lietuviškoji tarybine enciklopedija, Vol. II (Vilnius, 1968), p. 178.

${ }^{63}$ G. Vaskela, 'Lietuvos ūkis TSRS ir Rytų Pabaltijyje XX amžiaus $5^{-6}$ dešimtmečiais', in: Stalininis režimas Lietuvoje 1944-1953 m., ed. R. Laukaitytė (Vilnius, 2014), pp. $225^{-248 .}$

${ }^{64}$ Tarybų Lietuvos valstietija, p. 157. 
where various notes about the progress of collectivisation would be compiled. ${ }^{65}$

On the basis of these reports, the Lenin's Way kolkhoz grew more or less steadily, but it would not be wise to trust this information. The Soviet administration knew this as well: external inspection reports constantly pointed out that record-keeping at kolkhozes was not being conducted to a satisfactory standard, and even Soviet historiography admits that the reliability of reports up to 1955 was limited. ${ }^{66}$ Hints about the unreliability of reports could even be found in the press: for example, in February 1953 the newsletter of the Deltuva MTS political branch Kolektyvinis darbas [Collective Work] featured a caricature with the caption: 'Kolkhoz blacksmith: "When are we going to start repairs on the sowing machine?" Kolkhoz chairman: "Right now! According to the notes, it was repaired ages ago!"'67 The second reason why reports should not be trusted is that the illusion they reflect about the increase in economic output was created simultaneously by the amalgamation of kolkhozes, which increased the quantitative indicators at Lenin's Way. Specific inconsistencies between report data and the press are very noticeable. For example, in April ${ }^{1951}$ the same Kolektyvinis darbas newsletter, when praising Lenin's Way for its well-maintained farm, indicated that the kolkhoz had 21 pigs, of which three were sows that were raising 27 piglets. ${ }^{68}$ Meanwhile, report data indicates that on 1 January 1951, the kolkhoz had 122 pigs, of which 21 were sows. ${ }^{69}$

It is likely that the situation in the stock-breeding sector was catastrophic, and sources reveal facts that to some degree confirm this. For example, report data from 1950 shows that the kolkhoz's sows would farrow 70 piglets a year, yet an increase of only eight piglets was recorded..$^{70}$ Evidence of this also exists in a resolution

\footnotetext{
${ }^{65}$ Taršilova, 1948-1957 m. Lietuvos TSR kolūkiu metiniu apyskaitų respublikos suvestinès, p. 11.

${ }^{66}$ Ibid., p. 24.

${ }^{67}$ Kolektyvinis darbas, 24 April 1953.

${ }^{68}$ 'Gerai augina paršiukus', in: Kolektyvinis darbas, 22 April 1951.

${ }^{69}$ Lenin's Way kolkhoz annual report for 1951, in: VAA, col. 157, inv. 1, file 15, p. 9.

${ }^{70}$ Lenin's Way kolkhoz annual report for 1950, in: ibid., file 8, p. 8 .
} 
passed by the Ukmergè district executive committee on 30 October 1950, 'On Measures for Dealing with the Cruel Slaughter of Livestock and Wastage in the Ukmerge District', where the slaughter and sale of livestock without the authorisation of related institutions was completely banned. ${ }^{71}$ At the same time, this clearly shows that in reacting to collectivisation and the communalisation of property, instead of handing livestock over to the kolkhoz, the local population simply began to slaughter their animals on a mass scale.

It would appear that harvest productivity statistics in reports should raise less doubts, but even here the only criterion for reliability was the low value of the figures given. For example, in 1951 the winter wheat harvest at the Lenin's Way kolkhoz was $9.9 \mathrm{cwt} /$ ha, $6.7 \mathrm{cwt} / \mathrm{ha}$ of winter rye, $10.3 \mathrm{cwt} / \mathrm{ha}$ of summer wheat, and $9.5 \mathrm{cwt} / \mathrm{ha}$ of summer barley (including chaff)..$^{2}$ If we compare these figures to the Ukmerge district's averages in 1939, they were more than twice as high: $23.5 \mathrm{cwt} / \mathrm{ha}$ of winter wheat, $23.6 \mathrm{cwt} /$ ha of winter rye, and $21.7 \mathrm{cwt} /$ ha of summer wheat. ${ }^{73}$

Certain information about the economic situation of peasants, at least in the first years, is available in their property communalisation acts. However, not all have survived, and without knowing the circumstances in each case under which they were written up, their reliability cannot be properly assessed. Morever, the communalisation opened up a large grey area for 'human error': stealing, corruption and even empathy. For example, in a complaint from 1951, one kolkhoz chairman wrote that officials arrived and 'dekulakized' one kolkhoznik: they confiscated some of his property, applied higher taxes, and drafted a property communalisation act; and yet the next day they presented this farmer with a completely different document that listed much less property than the day before. ${ }^{74}$ Also, during their visit, the officials managed to steal some

${ }^{71}$ Ukmergė District Executive Committee of the Soviet of Labourers Resolution No 132, 'On Measures for Dealing with the Cruel Slaughter of Livestock and Wastage in the Ukmerge District', in: ibid., file 3, p. 1.

${ }^{72}$ Lenin's Way kolkhoz annual report for 1951, in: ibid., file 15, p. 5 .

${ }^{73}$ Lietuvos statistikos metraštis, 1939 (Vilnius, 1940), p. 100.

${ }^{74}$ Material regarding citizens' complaints and their discussion, in: LCVA, col. R-159, inv. 1, file 17, pp. 51-52. 
things from the kolkhoz itself. What is even more telling is that the regional executive committee declared that it was unable to clarify what had happened regarding an accusation of theft lodged against the officials (the militsiya was suggested instead), as the confiscated equipment had already been sold to other farms. ${ }^{75}$

Certain economic indicators are sometimes mentioned in kolkhoz meeting protocols, but they too raise some doubts, as it was basically only from 1953 or 1954 that it was revealed in meetings that livestock was dying (due to negligence and poor feed), although this problem had begun quite a bit earlier. Perhaps the change can be related to the mass inspections carried out at kolkhozes that began from 1953. Before then, there were practically no cases where livestock deaths had been identified as a systemic phenomenon; it was usually quoted as a condition put forward to further blacken the name of a person who had already transgressed (such as a farm manager). In this regard, kolkhoz minutes echo the prevailing trend both in historiography and in other Soviet literature: the shortcomings of collectivisation (the system) may be acknowledged; however, these shortcomings arose not due to the fault of the system, but due its poor execution by certain cogs of the system (people).

Thus, it is likely that in many cases we are talking about very limited sources, of poor reliability, which do not allow for the detailing of the economic output of kolkhozes, especially at the level of daily life. Sources reflect only the official facade of kolkhozes, the 'social' resources, while the private space practically remains hidden; we learn nothing of the individual o.6-hectare subsidiary plots of land of peasants, where the largest harvests were produced. We have practically no idea of the daily life, not only due to the nature of the sources, but also due to their unreliable content, which hides the reality. On the other hand, even though it is basically impossible to trace a specific quantitative economic decline (based on numbers and statistics), the qualitative decline is reflected somewhat better. 


\section{The early stagnation of agriculture}

When the Lenin's Way kolkhoz was created, one of the first tasks was to prepare for the forthcoming 1949 spring sowing season. In October, it had been decided to sow around 120 hectares of land with various crops (potatoes, barley, wheat, etc). After calculating who provided seeds and how much (the chairman and the partorg gave the most), it became apparent that 2,50o kilograms had been collected, approximately a fifth of the quantity required. It was decided to request the remaining 11 tonnes from 'the district'. ${ }^{76}$ We are talking about a relatively small area of land, 120 hectares, for which the kolkhoz could only gather barely a fifth of the total amount of seed that was required. It is no secret that the peasants would usually provide the poorest-quality part of their stocks for the kolkhoz's needs, so even that fifth was unlikely to be a realistic reflection of the situation, which in turn affected the size of the harvest.

The Ukmergè district executive committee distributed grain that had been confiscated from deportees, collected from peasant duties, and the like. According to data from a CPSU(b) CC notice, in 1948 the LSSR had fulfilled its grain duties ahead of time, and had even collected 9,6oo tonnes of excess grain. ${ }^{77}$ This would suggest that the kolkhozniki could have expected a more favourable verdict. However, in January 1949 the grain collection point warehouses in Ukmergè and Širvintos 30 kilometres away were inspected. Ukmergè was found to have 5,890 tonnes of grain in storage: 68 tonnes were rotten, at least $4,75^{8}$ tonnes were infested with parasites, more than 5 ,0oo tonnes of grain had not dried completely, and 386 tonnes were from the 1947 harvest and were not suitable for long storage. The situation in Širvintos was even worse: the grain was infested with parasites, only two of the 12 warehouses were suitable for storage, others were not suited for

\footnotetext{
${ }^{76}$ Lenin's Way kolkhoz meeting minutes, 24 October 1948, in: VAA, col. 157, inv. 1, file 1, p. 2.

${ }^{77} 20$ September 1948 (not earlier), Moscow CPSU(b) CC note 'On the Condition of Agriculture in the Lithuanian SSR', in: Lietuvos sovietizavimas 1947-1953 m.: VKP(b) CK dokumentai, ed. M. Pocius (Vilnius, 2018), p. 197.
} 
the purpose or were in an unsatisfactory condition, and one had a broken window, so snow would constantly cover the grain..$^{8}$

However, even seed of such poor quality was out of the kolkhoz's reach: officials from the Party apparatus who visited the farm explained that the kolkhozniki would have to provide most of the seed themselves, as the state could not allocate as much as was needed. ${ }^{79}$ It is likely that a similar situation was repeated continually: at the Ukmergè district Party conference in December 1950, Sergei Dushkin, the kolkhoz chairman at the time, complained that on numerous occasions he had appealed to both the regional Party committee and the executive committee regarding various issues, but had not received any support. ${ }^{80}$ However, had the state granted more grain as requested, the problem would still not have been solved, as records show that in many cases the peasants would simply consume part or even all of the grain allocated to them for sowing: either for sowing on their own personal plots of land, or feeding it to their livestock, or it would be stolen or distributed by other means.

Even greater economic decline was caused by the absurd work system imposed on kolkhozniki. The main unit of subsistence and work of kolkhozniks was the workday, whose essence Truska identified quite accurately, citing the writer Jonas Avyžius, who wrote that workdays 'started being measured on gram scales. ${ }^{81}$ Indeed, daily life at the kolkhoz could have been much worse. Already in 1949, members of the Lenin's Way kolkhoz only received barely one kilogram of wheat and one kilogram of barley, according to minutes, ${ }^{82}$ but there could have been a significant difference between what was entered on the workday document and what

${ }^{78}$ Ukmerge MVD special announcement to the Ukmergè CPSU(b) Executive Committee secretary, in: LYA, col. 78, inv. 3, file 13, p. 1.

${ }^{79}$ Žilènienè, 'Ukmergès rajono Deltuvos apylinkès „Lenino keliu“', p. 20.

${ }^{80}$ Ukmergè District First Party Organisation conference minutes (28-29 December 1950), in: LYA, col. 4510, inv. 1, file 2, pp. 10-11.

${ }^{81}$ L. Truska, 'Skaudi praradimų kaina. Mintys ir faktai apie pokario metų Lietuvos kaimą', in: Naujas požiūris į Lietuvos istoriją, eds. A. Eidintas, G. Rudis (Kaunas, 1989), p. 213 .

${ }^{82}$ Lenin's Way kolkhoz meeting minutes, 15 November 1949, in: VAA, col. 157, inv. 1, file 1, p. 20. 
the kolkhoznik actually received. Also, workdays would be paid for only at the end of the year. According to official (Soviet!) data, in 1952 , a monetary wage for labour was not being paid at more than half $(1,439)$ of the 2,628 kolkhozes, and at 624 farms less than one kilogram of grain would be given for a workday. ${ }^{8_{3}}$ MTS workers would also complain about unpaid wages, and Soviet historiography has also admitted the accumulated debts of kolkhozes. ${ }^{84}$ There are complaints, and even some protocol records that reveal cases where people working at a kolkhoz for an entire year had not received anything at all for their workdays. ${ }^{85}$

Thus, it is not at all surprising that another element of the Soviet economic system, the kolkhozniks themselves, had a very particular attitude towards work on this type of farm. They realised very soon that work on the kolkhoz was not like working for oneself but for a lord. With beginning of mass collectivisation in the USSR, the idea of a 'second serfdom's6 spread through rural areas, which was exactly how the Lithuanian partisans described collectivisation in their publications. ${ }^{87}$

The aforementioned spring sowing in 1949 did not go very well: the postponement of basically any type of farm work soon became an aspect of every-day kolkhoz life, as farmers would spend the mornings in their own private plots, rather than going to the kolkhoz fields. It was stated at a meeting on 7 May 1949 that only $5^{\circ}$ per cent of the sowing had been completed: there was a shortage of ploughs, most were faulty, there were no parts available to mend them, and the kolkhozniki (specially the women)

${ }^{83}$ Tarybu Lietuvos valstietija, p. 144.

${ }^{84}$ Ibid., p. 154.

${ }^{85}$ Material regarding citizens' complaints and their discussion, in: LCVA, col. R-159, inv. 1, file 19, p. 4; Molètai district, Kaližai county MTS Party Organisation meeting minutes, 5 July 1952, in: LYA , col. 4767 , inv. 1, file 1, p. 89.

${ }^{86}$ For more details, see: Fitzpatrick, Stalin's Peasants, pp. 128-151.

${ }^{87}$ For example, it was written in the Prisikèlimo partisan military district publication Prisikelimo ugnis in 1949: 'The Bolshevik state order is in essence nothing more than a revival of serfdom, only now it is promoted under the cover of new names and is being implemented using new, more refined methods,' in: LYA, col. K-5, inv. 1, file 142 . 
were not at all interested in working. ${ }^{88}$ It was constantly noted in the minutes that if people did go to work, it would not be in the mornings, but well into the day, or only in the afternoon. Older and infirm village dwellers who could not do physical work found themselves in a very bad situation: even though Soviet propaganda stated that the kolkhozes would have various social benefit mechanisms in place to look after those who were incapable of physical work, in most cases they were created late in the day, and even when they did exist they did not function properly, simply due to a lack of resources. This is also reflected in complaints whereby older people requested to be relieved of the duty to join kolkhozes, as, being too weak to work, they would not be able to earn a living. For example, an elderly man who joined a kolkhoz in 1949 complained that during the three years he spent there, the kolkhoz had not given him a single kilogram of grain. ${ }^{89}$

Both the sowing and the harvesting jobs were late, as well as the processing, because regardless of what size of harvest was brought in, the quality would be particularly bad. If this was not bad enough, even that meagre harvest would in most cases be wasted. For example, it was recorded that in February 1950, the grain at the Lenin's Way kolkhoz had still not been threshed. ${ }^{\circ}$ Due to such levels of negligence, no space had been prepared for drying or storing the grain, so quite often the whole harvest would be left outside in the open air, where it would be completely ruined by rain, and entire plots of land would be left unsown. From 1951, the new necessity of appointing harvest guards is a testimony to the increase in stealing, as is noted in the manuscript version of the memoirs of Kondratas, the chairman of Lenin's Way: guards were needed not so much for protection from external threats as from the kolkhozniki themselves. ${ }^{91}$ The situation in the livestock sector was just as catastrophic: on 15 November 1949, the shed still had

${ }^{88}$ Lenin's Way kolkhoz meeting minutes, 7 May 1949, in: VAA, col. 157, inv. 1, file 1, p. 12.

${ }^{89}$ Material regarding citizens' complaints and their discussion, in: LCVA, col. R-159, inv. 1, file 18, p. 98.

${ }^{90}$ Lenin's Way kolkhoz meeting minutes, 5 February 1950, in: ibid, file 3, p. 1.

${ }^{91}$ Kondratas, 'Tolimos pabarès' (MS), p. 214. 
no roof; in December it was admitted that there were no suitable spaces for keeping livestock, while the workers complained that they had nothing to give as feed. ${ }^{92}$ In March 1950, it was stated that the horses were being fed semi-rotten fodder; while the kolkhoz chairman was stealing fodder and 'getting drunk just about every day'; no one was looking after the animals, leading to their 'decline'; no one was accountable for the sowing; and the seeds had still not been winnowed. ${ }^{93}$

This situation was repeated every year, not just in Deltuva but across all of Lithuania. Vilnius and Moscow were well aware of the situation. In 1953, measures were taken to try to improve the state of the kolkhozes: it is stated in historiography that between 1953 and 1958, agricultural produce procurement prices were raised and the mandatory produce duty norms were reduced, ${ }^{94}$ though it is unlikely that this would have produced immediate results. At a Party Organisation meeting on 19 October 1954, it was stated that certain brigades had still not brought in the barley from the fields, and that no one was looking after the animals; on rainy nights they were still being kept outside, yet livestock had started dying in the farm sheds too. ${ }^{95}$ In November 1954, that is, before the winter had set in, the farm manager stated that in the last month, 33 calves had perished (or had to be 'finished off') due to poor-quality fodder. ${ }^{96}$

This makes the testimony of Kondratas, who became the Lenin's Way chairman in late 1954, very believable. In his memoirs, he wrote that when he became the chairman, the previous year's harvest only reached $4 \mathrm{cwt} / \mathrm{ha}$, while the livestock and fodder situation was so bad that a difficult decision had to be made: to slaughter the horses and feed the meat to the pigs. He gave away

${ }^{92}$ Lenin's Way kolkhoz meeting minutes, 1949 XII 19, in: VAA, col. 157, inv. 1, file 1, p. 21.

${ }^{93}$ Lenin's Way kolkhoz meeting minutes, 1950 III 18, in: ibid., file 3, p. 2.

${ }^{94}$ Bartuška, 'Lietuvos KP kaimo pirminių organizacijų veikla', p. 397.

${ }^{95}$ Lenin's Way kolkhoz Party organisation minutes, 19 October 1954, in: LYA, col. 9o, inv. 1, file 8, p. 16.

${ }^{96}$ Lenin's Way kolkhoz meeting minutes, 23 November 1954, in: VAA, col. 157, inv. 1, file 34, p. 39 . 
the same pigs to the kolkhozniki as bonuses, partly to increase their motivation, ${ }^{97}$ but also to relieve himself of the burden. The board meeting minutes and reports do not confirm Kondratas' version: the minutes show records that the decision had been made to sell almost half of all the farm's livestock, and the contents of the reports shows more or less the same results. Nonetheless, a rather pedantic censor (for example, one who did not allow a teacher to be shown working barefoot in a vegetable garden, because he was one of the intelligentsia), did not strike out a single word in the passage written by Kondratas: this implies that feeding pigs with the meat from slaughtered horses was not a shocking fact in Soviet society. Martinaitis tells a very similar story, about how in 1957 cows had to be rescued from the ice in a shed in the Raseiniai area where they were dying off. ${ }^{98}$ Even if we believe the official kolkhoz documents, such a sudden drop in livestock numbers could only mean one thing: the kolkhoz as an organisation could not sustain a farm of that size, and so it decided to relieve itself of surpluses, either as feed for other animals, selling it, or giving away the surplus.

During just about the whole period under discussion, both the workday record keeping and the work itself was very poorly organised, something the Party leaders were well aware of. Even a propaganda publication from 1958 intended for political purposes, entitled Agitatoriaus bloknotas [The Agitator's Notebook], contains the information that in most kolkhozes, money and products would be issued without taking into account the number of days worked, and these resources would be used for other needs. ${ }^{99}$ The workday system was absolutely ineffective: a brigade leader would be responsible for making a record of the workdays spent in the fields, sometimes he had to control brigades of over a hundred people. The bureaucracy reached such levels of absurdity that the number of workdays worked by all the kolkhozniki for a year had to be outlined in plans. For example, in $195^{\circ}$ it was planned

\footnotetext{
${ }^{97}$ Kondratas, Tolimos pabarès (published version), pp. 182-183.

${ }^{98}$ Martinaitis, Mes gyvenome, p. 172.

${ }^{99}$ Agitatoriaus bloknotas, 1958 (Vilnius, 1958), p. 7 .
} 
that Lenin's Way would use 49,582.3 workdays, while the members ended up working as many as $54,683.22$ workdays! They arrived at this surplus despite the fact that 413.8 workdays had to be written off for rule violations, even if there were not so many people who actually worked: the kolkhoz had 392 people capable of working; however, 118 did not work the minimum number of days, while 43 did not complete a single workday. ${ }^{100}$

The board, which also had to evaluate its own actions, did have a very broad scope for self-will. In this way, even the kolkhoz's most meagre resources would rarely reach the kolkhozniki: right into the start of the 196os, it was found that kolkhoz chairmen would pay themselves wages that were 20 to 30 times higher than those paid to the ordinary kolkhoznik. ${ }^{101}$ The Lenin's Way chairman was a little more modest: for example, in 1951 he only paid himself for 1,116 workdays. ${ }^{102}$ On the other hand, the rapidly formed nomenklatura of the kolkhoz managed to exploit the system's bias regarding the people who were directly involved: even when they worked particularly badly, they managed to avoid serious negative consequences. An illustrative example is the career of the first chairman of Lenin's Way. As has already been mentioned, Šemiota had already been a Party member in the interwar years, and after the war he became more seriously involved in the country's Sovietisation, which made him an ideal candidate for the position of kolkhoz chairman. Nonetheless, in March 1950, Šemiota was relieved from his duties. His dismissal was accompanied by a number of accusations: stealing fodder, drunkenness, not looking after the farm. Šemiota was used as a scapegoat for all the evils at the decaying farm. ${ }^{103}$ However, this alone did not yet signal the end of his career, regardless of the fact that even later sources would repeatedly highlight his drunkenness and other misdemeanours. When the amalgamation of kolkhozes began, Šemiota was

${ }^{100}$ Lenin's Way kolkhoz annual report for 1950, in: VAA, col. 157, inv. 1, file 8, p. 8.

${ }^{101}$ Comments on economic matters at kolkhozes, 196o-1961, in: LCVA, col. R-764, inv. 32, file 59, p. 23 .

${ }^{102}$ Lenin's Way kolkhoz annual report for 1951, in: VAA, col. 157, inv. 1, file 15, p. 17 .

${ }^{103}$ Lenin's Way kolkhoz meeting minutes, 18 March 1950, in: VAA, col. 157, inv. 1, file 4, pp. 2-3. 
made deputy chairman in January 1951. In November, he lost this position again, before being accepted on to the audit committee in December. We know that in $195^{2}$ he was still chairman of the Deltuva district, and a kolkhoz construction brigade in 1954. Also, throughout the decade, he remained an active member of the Party Organisation. He was only dismissed from his position when Kondratas became chairman, but he might even have been appointed somewhere else later on. According to Kondratas, firing Šemiota from his post as the construction brigade leader was one of his first aims, as he (Šemiota) '... no longer made any distinction between what was his and what belonged to the kolkhoz'. ${ }^{104}$ Another long-serving kolkhoz chairman faced similar 'problems'. Sergei Dushkin (a former Red Army soldier) also served as secretary of the Deltuva district executive committee, and ended up being replaced by Kondratas. According to him, Dushkin lost his position because he fell into a well when drunk, and had to be pulled out by the kolkhozniki. ${ }^{105}$ But in the minutes, the decision was formulated somewhat differently: Dushkin was held accountable for the serious stealing and embezzlement that had recently begun. ${ }^{106}$ The system's bias led to this kind of situation, but so too, possibly, did other reasons, the social connections that had formed at the top of the kolkhoz's hierarchy and in the regional governing institutions.

The system was so absurd and dysfunctional that undertaking a more detailed analysis is not worthwhile. It suffices to say that the kolkhoz was completely incapable of seeing to the needs of the kolkhozniki: even based on annual reports, the kolkhoz was always in debt, in the form of grain and money for workdays alone, weighed out on gram scales. As a result, working habits and the work culture declined catastrophically, while people had to survive by concentrating on their individual farms (plots of land), hiding animals, stealing and 'wangling' what they could. Reports by government officials from 1957 also recorded that in some

${ }^{104}$ Kondratas, Tolimos pabarès, p. 184.

${ }^{105}$ Ibid.

${ }^{106}$ Lenin's Way kolkhoz meeting minutes, 19 December 1954, in: VAA, col. 157, inv. 1, file 34, p. 44 . 
cases subsidiary plots of land would increase in size to several hectares, and animal numbers there also exceeded the norms. ${ }^{107}$ A cow was the most important permanent source of food. In recollections that somewhat idealise kolkhozes, a former farmer from the Kamajai area claimed how until 1962, in rural areas 'the cow was the main means of subsistence,' and if any family lost their cow (if it stopped giving milk, or died), other kolkhozniki would try to collect money for the unlucky family. ${ }^{108}$ The sources that were analysed confirm the thesis of the historian Gediminas Vaskela that at the beginning of the 1950s (and probably for some time afterwards) collectivisation totally destroyed agriculture in all the Baltic republics. ${ }^{109}$ According to Fitzpatrick, between 1953 and 1967 , the income the average USSR kolkhoznik received from the farm (not their personal plot of land) increased by 311 per cent. ${ }^{110}$ On the other hand, the system remained very rigid, and could not eliminate its shortcomings: if we use the above figures for our calculations, a 311 per cent shift from one kilogram of oats and one kilogram of barley to three kilograms of oats and three kilograms of barley for workdays does not seem very impressive. Soviet agriculture was in a state of paralysis. Rampant drunkenness, stealing and 'bringing back' from the kolkhoz was the totally logical and expected outcome of the implementation of the kolkhoz system.

\section{Conclusions}

1. For a long time, the Bolsheviks suggested seeing collectivisation as ideologically motivated economic reform ('the reorganisation of agriculture in line with socialist foundations'); however, the economy was merely a facade for this reform. The real point of the reform was political: to take control of rural areas, and ultimately Sovietisation. Having stated this, it was not the occupying regime's

${ }^{107}$ Reponse from the LSSR Ministry of Agriculture to the Board of Kolkhoz Organisational Affairs, 23 November 1957, in: LCVA, col. R-764, inv. 32, file 56, p. 123.

${ }^{108} \mathrm{~J}$. Baraišienè, 'O kolūkyje buvo taip', in: Kamajai, ed. V. Mačiekus (Vilnius, 2016), p. 357 .

${ }^{109}$ Vaskela, 'Lietuvos ūkis TSRS', pp. 230-232.

${ }^{110}$ Fitzpatrick, Stalin's Peasants, p. 317. 
economic policy (land reform, taxes, grain tax [paid in kind]) that was one of the more important factors in the history of collectivisation, but the political context: the ten years of living in a state of constant war and terror in Lithuania. These circumstances had totally exhausted Lithuanian society, the ever-growing fear among the people prompted an ever-greater need for peace, and at the same time it changed their relationship with the occupying regime and the resistance movement, urging them to search for ways of adapting. This was reasonably a more effective means of controlling people than the tools of the Soviet economy: land reform, grain taxes and other taxes.

2. The Lenin's Way kolkhoz, which was formed under duress in the summer of 1948, existed essentially just 'on paper' until at least the spring of 1949. Over this period, the number of members of the kolkhoz fluctuated: when it was founded, there were formally 62 people; however, this figure soon fell to eight. The kolkhoz could not deal with even the most routine challenges, while all kinds of work failed. Thus, the statistics that appear in historiography and Soviet literature which show collectivisation as focused and consistent reform, that is, statistics that highlight how the number of kolkhozes in Lithuania increased year by year, do not show this important dynamic of collectivisation. Nonetheless, even the forced establishment of the kolkhoz 'on paper' was important to the regime: it meant that a basis for the kolkhoz could be established, peasants who tried to leave would not be able to recover their land or equipment, and living outside the kolkhoz structure was practically impossible because of the tax burden. An important factor in the establishment and sustainability of kolkhozes was the mass deportation operations in 1948 and 1949, which served to further terrify the local population.

3. Kolkhozniki found themselves in the difficult Soviet bureaucratic system: the kolkhoz was not autonomous, but tied up by various bureaucratic bonds, both internal and external. According to the Standard Charter for agricultural artels, the main institution in the life of the kolkhoz was supposed to be the general meeting, but it became clear from around 1950 that the entire management at Lenin's Way had fallen into the hands of the chairman and 
the board, and general meetings were no more than a formal procedure during which annual reports and changes to the board would be confirmed: the voice of the kolkhoznik had practically no meaning at all. This was a natural outcome of the establishment of the kolkhoz system: the kolkhoz was managed by a group of people who were favoured by the Soviet system: former frontliners, the so-called annihilation battalions (istrebitel'nye batal'ony), officials from other Soviet structures, and their family members. This group of ten to 15 people is the most represented group in kolkhoz documents, which is why, when studying these historical sources, we can reconstruct the development of the kolkhoz as a kind of pseudo-economic unit, but we certainly cannot reveal a detailed and multi-faceted picture of daily life at the kolkhoz.

4. Due to the specific nature of the sources and their unreliability, it is difficult to determine with any great accuracy just how much the Lithuanian agricultural sector declined after collectivisation; however, it is quite evident even in Soviet sources that there was a decline, and its description requires more than just a mathematical expression. It became rather clear very soon that the kolkhoz was in no way capable of ensuring any form of stability: harvests declined, as did the livestock sector and people's faith in the 'welfare state' imagery promoted in Soviet propaganda. Kolkhozes floundered from their very inception: they failed to grow, and year after year, kolkhozniki went without being paid for their workdays. In the case under analysis, the best reflection of this situation was the winter of 1954 and 1955, when the kolkhoz did not have enough fodder for its livestock, and was forced to slaughter the horses, whose meat was used to feed the pigs, which were in turn given away to the kolkhozniki (as payment in kind). That is why the appearance of statistics in historiography about the Soviet Lithuanian agricultural sector can only reflect some of the truth: apart from the declining economic indicators, it is also critical to note the qualitative difference in agricultural production, the work culture, people's attitudes towards work, and living conditions. 
Author Details

Antanas Terleckas is a doctoral student in the Faculty of History at Vilnius University. He is writing his dissertation on the topic 'The Creation of a Kolkhoz Society: The Sovietisation of Rural Lithuania in 1940-1965'.

Email: antanasterleckas@gmail.com

\section{Bibliography}

Agitatoriaus bloknotas, 1958 (Vilnius, 1958).

BALŽENTIS, Alvydas, Pranas SASNAUSKAS, Kazys STARKEVIČIUS. Kolūkmetis okupuotos Lietuvos kaime (Vilnius, 2019).

BARAIŠIĖNĖ, Janina. 'O kolūkyje buvo taip', in: Kamajai, ed. V. Mačiekus (Vilnius, 2016), pp. 356-358.

BARTUŠKA, V. ‘ Lietuvos KP kaimo pirminių organizacijų veikla, vystant žemdirbių gamybini aktyvumą 1952-1958 metais', in: Už socializmo sukūrimą Lietuvoje (Vilnius, 1969).

Boleslovo Miškinio-Šarūno atsiminimai, in: Aukštaitijos partizanų prisiminimai, Part III, ed. R. Kaunietis (Vilnius, 2001).

BUBNYS, Arūnas. Vokiečiu okupuota Lietuva (1941-1944) (Vilnius, 1998).

BUKAVICKAS, Rubenas. Sovietizacija Klaipèdos krašte: sociokultūrinès ir socioekonominès transformacijos 1945-196o metais, doctoral dissertation (Klaipèda, 2020).

The Collectivization of Agriculture in Communist Eastern Europe: Comparison and Entanglements, ed. by C. Iordachi, A. Bauerkämper (New York, 2014).

'Deltuva', in: Lietuviu enciklopedija, Vol. IV (Boston, 1954), pp. 430-431.

'Deltuviečiai jungiasi ị kolūkius', in: Tarybinis kelias, 7 July 1948.

FEEST, David. Zwangskollektivierung im Baltikum: die Sowjetisierung des estnischen Dorfes 1944-1953 (Köln/Wien, 2007).

FIZPATRICK, Sheila. The Russian Revolution (Oxford, 2017).

FITZPATRICK, Sheila. Stalin's Peasants: Resistance \& Survival in the Russian Village After Collectivization (New York, Oxford, 1994).

'Gerai augina paršiukus', in: Kolektyvinis darbas, 22 April 1951.

GIRNIUS, Kęstutis. 'The collectivisation of Lithuanian Agriculture, 1944-1950', in: Soviet Studies, Vol. 40, No 3 (July 1988), pp. 46o-478.

GREGORAUSKAS, Marijonas. Tarybu Lietuvos žemès ūkis, 1940-196o (Vilnius, 196o).

Hitleriné okupacija Lietuvoje (Vilnius, 1961).

GRUNSKIS, Eugenijus. Lietuvos gyventojų trèmimai 1940-1941, 1945-1953 metais (Vilnius, 1996). 
KLIGMAN, Gail, Katherine VERDERY. Peasants under Siege: The Collectivization of Romanian Agriculture (Princeton, 2011).

Kolektyvinis darbas, 24 April 1953.

KÕLL, Anu Mai. The Village and the Class War: Anti-Kulak Campaign in Estonia (Budapest, 2013).

'Kolūkiai, kolektyviniai ūkiai', in: Mažoji lietuviškoji tarybinè enciklopedija, Vol. II (Vilnius, 1968), p. 178.

KONDRATAS, Juozas. Tolimos pabarès (Vilnius, 1971).

KOTKIN, Stephen. Magnetic Mountain: Stalinism as a Civilization (Berkeley and Los Angeles, 1997).

KRANIAUSKIENĖ, Sigita, Silva POCYTĖ, Ruth LEISEROWITZ, Irena ŠUTINIENĖ. Klaipédos kraštas 1945-1960 m.: naujos visuomenès kūrimasis ir jo atspindžiai šeimu istorijose (Klaipèda, 2019).

MARTINAITIS, Marcelijus. Mes gyvenome: biografiniai užrašai (Vilnius, 2010).

MINCYTÉ, Diana. 'Everyday Environmentalism: The Practice, Politics, and Nature of Subsidiary Farming in Stalin's Lithuania', in: Slavic Review, Vol. 68, No 1 (Spring, 2009), pp. 31-49.

Paryzdiniai žemés ūkio artelès įstatai (Vilnius, 1949).

POCIUS, Mindaugas. Kita ménulio pusé: Lietuvos partizanu kova su kolaboravimu 1944-1953 metais (Vilnius, 2009).

POCIUS, Mindaugas. 'Lietuvos kolektyvizacija 1947-1952 m.: VKP(b) CK sprendimai ir kontrolè', in: Genocidas ir rezistencija, 2018, 2(44), pp. 7-14; Genocidas ir rezistencija, 2019, 1(45), pp. 72-85.

PUTINAITĖ, Nerija. Nenutrūkusi styga: prisitaikymas ir pasipriešinimas sovietu Lietuvoje (Vilnius, 2007).

Tarybu Lietuvos valstietija: istorijos apybraiža, ed. H. Šadžius (Vilnius, 1979).

TRUSKA, Liudas. 'Lietuvos valstiečių kolektyvizavimas', in: Lietuvos istorijos metraštis, 1988 metai, pp. 79-9o.

TRUSKA, Liudas. Lietuva 1938-1953 metais (Kaunas, 1995).

TRUSKA, Liudas. 'Skaudi praradimų kaina. Mintys ir faktai apie pokario metų Lietuvos kaimą', in: Naujas požiūris į Lietuvos istoriją, eds. A. Eidintas, G. Rudis (Kaunas, 1989).

SNYDER, Timothy. Bloodlands: Europe between Hitler and Stalin (New York, 2010).

STARKAUSKAS, Juozas. Čekistine kariuomenè Lietuvoje 1944-1953 metais (Vilnius, 1998).

STARKAUSKAS, Juozas. Represiniu struktūru ir komunistu partijos bendradarbiavimas ịtvirtinant okupacini režima Lietuvoje 1944-1953 m. (Vilnius, 2007). 
STREIKUS, Arūnas. 'Sovietinis kaimas ir erdvès užvaldymas', in: $P a-$ sakojimas tęsiasi: modernizacijos traukinyje. Lietuvos šimtmetis, 1918-2018, eds. G. Jankevičiūtè, N. Šepetys (Vilnius, 2018), pp. 108-117.

TARŠILOVA, Tamara. 1948-1957 m. Lietuvos TSR kolūkiu metiniu apyskaitu respublikos suvestines (Vilnius, 1986).

'TSRS Aukščiausios Tarybos Prezidiumo įsakas Dèl Lietuvos TSR darbininkų, valstiečių ir priešakinès inteligentijos atstovų apdovanojimo ordinais ir medaliais', in Tarybinis kelias, 23 July 1949.

VASKELA, Gediminas. 'Lietuvos ūkis TSRS ir Rytų Pabaltijyje XX amžiaus 5-6 dešimtmečiais', in: Stalininis režimas Lietuvoje 1944-1953 m., ed. R. Laukaitytè (Vilnius, 2014), pp. 225-248.

VIOLA, Lynne. The Best Sons of the Fatherland: Workers in the Vanguard of Soviet Collectivization (New York, Oxford, 1987).

ZUBKOVA, Jelena. Pabaltijys ir Kremlius 1940-1953 m. (Vilnius, 2010).

\section{LIETUVOS KAIMO SOVIETIZACIJA: DELTUVOS APYLINKIŲ KOLCHOZO „LENINO KELIU“ ATVEJIS (1948-1957)}

Santrauka

\section{ANTANAS TERLECKAS}

Straipsnyje analizuojama Lietuvos kaimo sovietizacija per vieno atvejo - Deltuvos apylinkèse (Ukmergès raj.) veikusio kolchozo „Lenino keliu“ - istoriją. Šis atvejis pasirinktas dèl išlikusios plačios ir įvairios kolchozo šaltinių bazės bei jo ankstyvo įkūrimo, t. y. 1948 m. vasarą, aplinkybių. Šiame straipsnyje bandoma detaliau, nei iki šiol tai daryta istoriografijoje, pažvelgti i procesus, vykusius konkrečiame Lietuvoje įsteigtame kolchoze, o tai leidžia sukonkretinti daugelį istoriografijoje ịsitvirtinusių palyginti aptakių teiginių apie žemės ūkio smukimą kolektyvizacijos metais. Tyrimas atskleidè, kad kolchoze gana sparčiai susiformavo savotiškas nomenklatūros sluoksnis, perėmęs kolchozo valdymą i c savo rankas, Daugiausia tai buvo su režimu vienaip ar kitaip susiję asmenys (partijos nariai, Raudonosios armijos veteranai, stribai ir jų artimieji). Dèl šių žmonių ir pačios sistemos veikimo principų labai greitai visuotiniai kolchozo susirinkimai, turèję būti svarbiausiu kolchozo valdymo organu, prarado ši vaidmenį ir pasidarè grynai formalia institucija. Tai taip pat prisidejo prie absoliučiai neveiksnios socialinės ekonominès sistemos, kuri neskatino jokio joje atsidūrusių žmonių suinteresuotumo savo darbu, sukūrimo. Todèl Lietuvos žemès ūkis patyrẻ katastrofišką nuosmuki - net ne tiek kiekybinį, kiek kokybinį. 